University for Business and Technology in Kosovo

UBT Knowledge Center

Oct 28th, 5:00 PM - 6:30 PM

\title{
Family cohesion as important factor for attitudes towards psychoactive drugs in adolescence
}

\author{
Hana Saliu \\ University of Tetova, hana.saliu@unite.edu.mk \\ Myqereme Rusi \\ m.rusi@yahoo.com \\ Dega Marku \\ degam94@hotmail.com
}

Follow this and additional works at: https://knowledgecenter.ubt-uni.net/conference

Part of the Psychology Commons

\section{Recommended Citation}

Saliu, Hana; Rusi, Myqereme; and Marku, Dega, "Family cohesion as important factor for attitudes towards psychoactive drugs in adolescence" (2017). UBT International Conference. 328.

https://knowledgecenter.ubt-uni.net/conference/2017/all-events/328

This Event is brought to you for free and open access by the Publication and Journals at UBT Knowledge Center. It has been accepted for inclusion in UBT International Conference by an authorized administrator of UBT Knowledge Center. For more information, please contact knowledge.center@ubt-uni.net. 


\title{
Family cohesion as important factor for attitudes towards psychoactive drugs in adolescence
}

\author{
Hana Saliu; Myqereme Rusi; Dega Marku \\ Tetova State University, Street Ilinden bb 1200, Tetovo 1220, Macedonia \\ hana.saliu@unite.edu.mk,m.rusi@yahoo.com \\ degam94@hotmail.com
}

\begin{abstract}
Adolescence is a fragile period in which the person passes from the childhood to the adulthood. During this period the adolescent passes through different challenges. Adolescent has to deal with physical, physiological, emotional, cognitive, social and other changes, and during his journey family as a social factor has the most important part, because with their support they help the adolescent to overcome all the difficulties on his way. Because of the function and the importance that family has over the adolescent, in this research we have measured the correlation between family cohesion and the attitudes towards psychoactive drugs, because as we know adolescents are usually more likely to use psychoactive drugs. The research has been applied to 116 subjects, whose age is between 17 and 18 years old. As a measure instruments for the research are used Kobi test for family cohesion, and a questionnaire that measures the attitudes towards psychoactive drugs. The obtained results has shown that exists a negative correlation between family cohesion and positive attitudes towards psychoactive drugs, which means that the adolescents that have high family cohesion, don't have positive attitudes towards psychoactive drugs.
\end{abstract}

Keywords: family cohesion, attitudes, adolescent, psychoactive drugs.

\section{Introduction}

Adolescence is the age where the young man gives voice to his own thoughts and great importance to things that later in life will have no value for him. In this period, very common occurrence among young people is conformism, but not with parents and family, but with their peers. Because teenage relationship- parents for some time start to distance themselves slightly, adolescents on the other hand tend to see and recognize the world in a different prism, far from the eyes of the parents as they were taught. They begin to have their own thoughts, own feelings and beliefs about different phenomena, different events and different people. No wonder if we see an adolescent that values his or her friend opinion more than he values the opinions of his parents or his professors. Therefore, as a result of this "disconnection" that occurs between a teenager and his parents, came the idea to measure family cohesion among adolescents, which as a concept inherits something more intimate, emotional relationship or support, between family members, and also the idea how family cohesion relates with adolescents attitudes towards psychoactive drugs. Also, considering the fact that "the child does not arise with negative attitudes but gains them", we wanted to prove that in fact how does the emotional connection affects adolescents to have positive attitudes towards psychoactive drugs. Actually, it is believed that society plays the main role in adolescents thoughts, feelings and actions, but in this case, we think that we need to verify what role the family plays in shaping attitudes towards psychoactive drugs in adolescence. 


\section{Family cohesion}

Not all of the theorists defined family cohesion the same way, however Olson (1993, pg.105) provided perhaps the clearest definition of cohesion. He stated: "family cohesion is defined as the emotional bonding that family members have toward one another". Moos and Moos (1989) conceptualized cohesion to include the degree of commitment help and support family members provide for one another. Cohesion is one of the fundamental dimensions of which the structure of the group varies. It is the degree of desire by which members of a group want to continue to be its members or otherwise said is the measure by which members of a group withdraw from each other. Groups where members are committed to the group and strongly attracted to it, possess high cohesion, while those with little mutual attraction are groups of low cohesion. So the cohesiveness of the group is the social-psychological equivalent of the feeling of commitment and liking for the group.

Family cohesion implies the "emotional bond that exists among family members" (Olson, 2000, pg. 145). Family cohesion is defined as " the amount of anger and conflict expressed among members of the family". Kissane et al. Reported that family cohesion was an important element for imitation of the family. Previous studies have suggested that high levels of support and low levels of conflict can help family members better cope with personal and family problems.

Family cohesion reflects the emotional attachment of family members, said otherwise: their emotional distance or closeness, the time they spend together, the ways the make a decision, their common fun and interests (Olson, Portner \& Bell, 1983). The assessment of the above factors helps to determine the level of family cohesion. Families with a low level of cohesion are characterized by the concept of "emotional separation", while high-cohesive families have a "strong bond" or "high consensus" family as their basic qualities. In families with low cohesion, family members feel a limited emotional connection between them, each of which deals with their own interests and cares little about other members. Different interests prevail, and family members can't seek help and support in their family, especially if they face difficulties. The members of this family are described as being emotionally distracted from one another. Families that pass through the low level and reach the middle level of cohesion usually work well and are balanced, giving more importance to personal than family interests. However, in these families, family members find time for common interests, sometimes make decisions together, or support each other in difficulty (Olson, Portner \& Bell, 1983). The members of this family are considered to be emotionally separated from one another.

Families with middle cohesion are also considered as balanced families, characterized by faith in the role of family and dedication to family bond. Although family members have common interests, common friends, they also have personal interests at the same time. The members of this family are considered to be affiliated emotionally with one another.

On the other hand, families with high cohesion have family members that are dependent on each other, and are unable to meet their personal interests, which are very limited. The members of this family are considered to be very emotionally connected with each other. Families with high cohesion are considered balanced and assist in the development of children (Olson, 1993).

\section{Psychoactive drugs}

Psychoactive drugs are substances that act on the nervous system to change the state of consciousness, to modify perceptions and to change the mood. Psychoactive drugs usually activate dopamine receptors in brain pathways, ranging from the limbic system to the prefrontal area. Based on various assessments in the world it has resulted that thee are over 200 million psychoactive drug abusers. Research shows that the most common reasons why young people consume psychoactive drugs are: personal satisfaction, temporary adaption, to free themselves from tension, to remove boredom and fatigue, to escape from the harsh reality surrounding them, 
for curiosity, but also from social pressure, which implies the pressure of society to conform to others, and to feel alike other people that use these psychoactive drugs. Continued use of psychoactive drugs can lead to addiction and tolerance. By tolerance we mean the need to increase the dose of consumption to have the same effect, while addiction can be physical a psychological, and the withdrawal from them can lead to such symptoms, such as: insomnia, vibration, nausea, stiffness, blood pressure, increased heart beat, anxiety, and depression.

Psychoactive drugs are generally classified into three major groups: depressants, stimulants and hallucinogens. Depressants reduce physical and psychological activity of the individual. Stimulants increase the activity of the nervous system, while hallucinogens modify perceptions as well as produce unusual visual images. Depressants include alcohol, sedative, narcotics. Stimulants include caffeine, amphetamine, ecstasy and nicotine. While hallucinogens include marijuana. In this research in measured adolescents attitudes towards psychoactive drugs, and how they relate with family cohesion.

\section{Methodology}

The main problem in this research is to explore : "Is there a negative correlation between adolescent's family cohesion and their attitudes towards psychoactive drugs ?"

The main purpose of this research is to prove that there is a negative correlation between adolescent's family cohesion and their attitudes towards psychoactive drugs.

The research hypothesis is: Adolescents with high family cohesion have negative attitudes towards psychoactive drugs.

The population of this research has been selected in random. As a sample in which this research was applied are high school students of "Niko Nestor " and "Ibraim Temo" in the city of Struga. The respondents involved in the research are mainly students of the third year. There are altogether 116 subjects, of whom 80 are women, and only 36 are males. The subjects of the sample were all from Struga, of whom 35 come from the city, and 81 subjects came from the village. 


\section{Results}

Descriptive statistics for the two main variables "Family cohesion" and "Attitudes towards psychoactive drugs", are given in table 1, in which are shown: the total number of the subjects, the highest score, the lowest score, mean and the standard deviation.

Tabela 1. Descriptive statistics for the main variables

\begin{tabular}{|l|l|l|l|l|l|}
\hline & $\mathrm{N}$ & Lowest score & Highest score & $\mathrm{M}$ & $\mathrm{SD}$ \\
\hline Cohesion & 116 & 119 & 270 & 243.6207 & 28.75886 \\
\hline Attitudes & 116 & 23 & 52 & 35.1724 & 6.29876 \\
\hline
\end{tabular}

Based on the descriptive analysis of the 116 subjects it is found that the mean of the "Family cohesion" variable i $(M=243.62)$, with minimal value $(\min =119)$ and maximum value $(\max =270)$. According to this value, we notice that the average of subjects for this variable has resulted over the expected real average $(\mathrm{M}=135)$, respectively we conclude that there is a high level of presence of this variable in the relevant subjects, which means that the level of family cohesion is very high on adolescents, with a standard deviation ( $\mathrm{std}=28.75)$. As for the second variables "Attitudes towards psychoactive drugs", based on the descriptive data of the 116 subjects, it is found that the mean of the variable is $(M=35.17)$, with a minimum value ( $\mathrm{min}=23$ ) and maximal $(\max =52)$. According to this value, we notice that the average of subjects for this variable has been below the expected real average $(M=50)$, respectively we conclude that there is a low level of this variable in the relevant subjects, which means that the level of attitudes towards psychoactive drugs is negative, with a standard deviation ( $(\mathrm{std}=6.29)$.

To find the correlation between two main variables such as "Family cohesion" and "Attitudes toward psychoactive drugs", was used the Pearson correlation method.

Table 2. The correlation coefficient for Family cohesion and Attitudes towards psychoactive drugs variables.

\begin{tabular}{|l|l|l|l|}
\hline \multirow{3}{*}{$\mathrm{K}$} & & $\mathrm{K}$ & $\mathrm{P}$ \\
\hline \multirow{4}{*}{$\mathrm{P}$} & Pearson Correlation & 1 & $-.234^{*}$ \\
\cline { 2 - 4 } & Sig. (2-tailed) & & .011 \\
\cline { 2 - 4 } & $\mathrm{N}$ & 116 & 116 \\
\cline { 2 - 4 } & Pearson Correlation & $-.234^{*}$ & 1 \\
\cline { 2 - 4 } & Sig. (2-tailed) & 011 & \\
\cline { 2 - 4 } & $\mathrm{N}$ & 116 & 116 \\
\hline
\end{tabular}

*. Correlation is significant at the 0.05 level (2-tailed).

Based on the Pearson coefficient $(\mathrm{r}=-0.234)$, which measures the correlation between the two main variables, we conclude that these two variables possess a negative correlation. This implies that with the rise of the "Family cohesion" variable in adolescents, positive attitudes towards psychoactive drugs decrease. The higher the family cohesion, the more negative the attitudes towards psychoactive drugs to adolescents. From the obtained results it can be noticed that the negative correlation obtained between the "Family cohesion" and "Attitudes toward psychoactive drugs" variables is significant at 0.05 level. Based on this we can say that the hypothesis set out in this research is verified. 


\section{Conclusion}

This research has two main variables: "Family cohesion" and "Attitudes towards psychoactive drugs", which are applied at high school students in city of Struga. From this research we found out that exists negative correlation between these two main variables included in the paper work. This implies that: with the increase of family cohesion in adolescents, attitudes towards psychoactive drugs decrease. The obtained result from the analysis of this research support the main hypothesis on the research, which means that there is a negative correlation between the two variables. The assumption of why this may have resulted, in our opinion, is that adolescents in this transition period of their lives, even thought it seems like they are not too affiliated to their parents, still family members have particular importance for adolescents. They are greatly affected by family bond and if these relationships are warm between adolescents and their family members, if adolescent is understood by the family, and enables the expression of the adolescent's personality in the family, all these will influence in adolescents attitudes towards many different issues, as well as their attitude towards psychoactive drugs. From this research we can conclude that no matter how much adolescent is conformist and connected to society, the family atmosphere of family cohesion always will influence the decisions and assessments that adolescent make of different social phenomena. An adolescent that has high family cohesion and personal space, may have negative attitudes towards psychoactive drugs.

\section{References}

1. Dragoti, E. (1999). "Psikologjia sociale“. Tiranë: Libri Universitar

2. Kashahu, L. (2010). Ndikimi i funksionimit familjar dhe bashkepunimit familje-shkolle ne perparimin e adoleshenteve. Punim Doktorature, Universiteti i Tiranës

3. Miller, A. L. \& Tucker, C. (1993). THE INTRAHOUSEHOLD COMMUNICATIONS

STUDY: A TYPOLOGY OF FAMILY COHESION. E lexuar më 5 shtator 2017, nga vebfaqja: https://www.amstat.org

4. Moos, R. H. and Moos, B. S. (1986) The Family Environment Scale: The manual. Palo Alto CA: Consulting Psychologists Press.

5. Olson, D.H., Porter, J. \& Bell, R. (1983). Family adaptability and cohesion evaluation scores [FACES] II (1982). Filsinger, E. E. (Eds). Marriage and family assessment: A sourcebook for family therapy. Beverly Hill, CA: Sage.

6. Olson, D. H. (1993). Circumplex Model of marital and family systems: Assessing family functioning. In Walsh, F. (Ed.), Guilford family therapy series. Normal family processes (pp. 104-137). New York: Guilford Press.

7. Olson, D. (2000). Circumplex Model of Marital and Family Sytems. Journal of family therapy. Volume 22, Issue 2, May, Doi: 10.1111/1467-6427.00144.

8. Sapp, R. L. (2003). Family Conflict and Family Cohesion: Their Relationship to Youths' Behavior Problems. Punim Doktorature, University of Tennessee

9. Smiljanic, V. (1979). "Psihologija starenja", Beograd: Nolit 